\title{
HEREDITY IN THE HONEY-BEE
}

\author{
P. W. Whiting \\ Child Welfare Research Station, State University of Iowa
}

$I_{\mathrm{t}}^{\mathrm{T}}$ $T$ IS now generally recognized that inheritance in the honey-bee is of a criss-cross type due to the fact that males or drones arise from unfertilized eggs and thus inherit maternal characters only. Females, both workers and queens, come from fertilized eggs and thus show paternal as well as maternal qualities. These three castes are strikingly different from each other both in structure and in instincts. From measurements made by v. Alten and published by Armbruster it appears that the "brain-index" of workers is superior to that off the : queen and the latter again simerior to that of the drone. Degeneration of the queen brain is correlated with diegeneta tion of instincts due to a "parasitic". life upon the worker colony. Instyncts. as well as brain of the drone are:bike: wise far inferior to that of the workers.

\section{PROBLEMS OF HEREDITY}

In a recent book on bees ("A Book about the Bee" by Herbert Mace) occur the following remarks:

"The curious problem, and one that is not to be explained by any law that we are cognisant of, is that the workers with all their wonderful cell-building, pollen-gathering, and honey-storing appliances and instincts, descend from parents who have never done any thing of the kind, having neither the organs nor the requisite amount of intelligence. How is this complex instinct transmitted?"

"The drone is a male bee, having neither the organs nor the intelligence to perform the necessary functions of existence apart from the colony. The queen is more or less in like case. Neither is able to find food for itself. Neither has ever had anything to do with the rearing of the young. Yet the product of the two is, under ordinary circumstances, an insect endowed with special apparatus for carrying home honey and pollen in quantities truly remarkable for the size of the creature. Its tongue, honey sac, and pollen baskets are developed in a measure that has no comparison with those of its parents. In addition it possesses a much higher degree of intelligence as calculated by brain area."

"The female or queen bee, contains within her own person the means of reproducing bees, but not bees that are in any way like herself. Her unassisted progeny is of a kind entirely different in: its organic structure. In athis:she: differs from the aphides. The offspiring of a virgin.aphis is like herself, a fénate : $\because \because \because$

:? a drones have a mother, but no fathar. How comes it then that Ihey fossess the virtues, or perhaps we sfrould say vices, of a parent who has taken no part in their production?

"Of course it is true that the drones which come from a certain queen are generally pure, that is to say, the particular variety of bee, whether Black, Italian, or Carniolan, which the queen belongs to is perpetuated in the drone."

"Skilled apiarists know well that qualities, even to the minute shades of difference are thus perpetuated. A stock that is naturally vicious and inclined to sting at every opportunity can be cured of the propensity by removing the queen and substituting one from another and more gentle colony. On the other hand if we have a colony which is notable for its devotion to work, for its capacity to extract honey from specially inaccessible flowers, or for the exceptional colour and beauty of its wax, we take great pains to rear future queens from that colony, knowing that their offspring will assuredly possess the same qualities. And yet, so far as we can trace back through the ages, the queen has never performed any of the duties so pre-eminent in her offspring." 

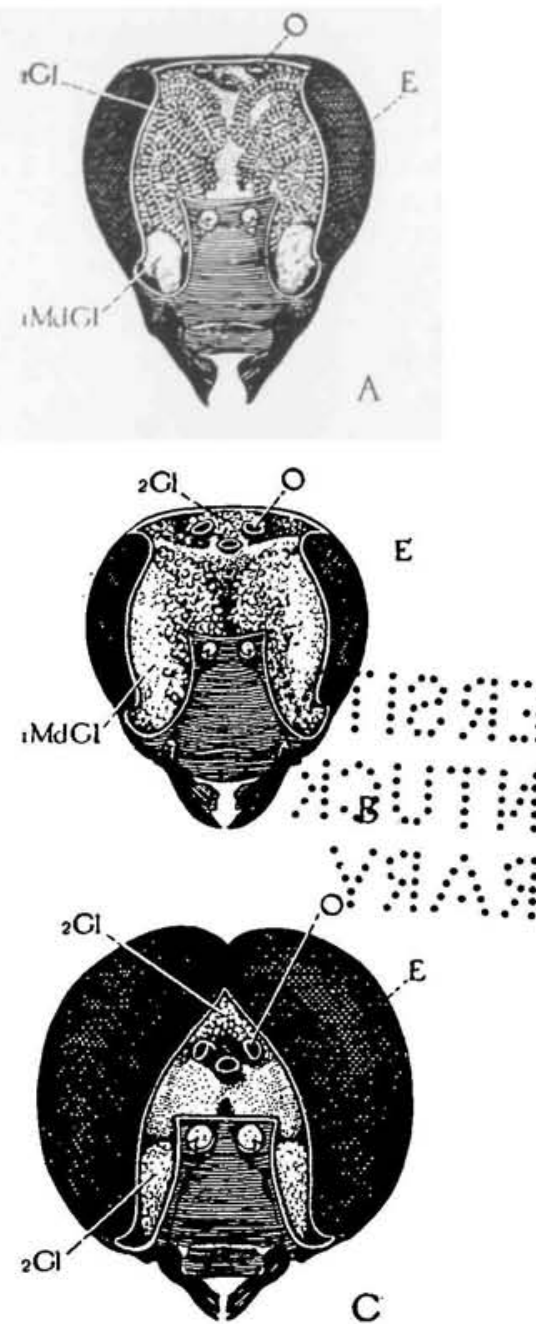

ANTERIOR VIEW OF HEADS OF WORK-

ER (A), QUEEN (B) AND DRONE (C)

The front chitin has been removed to show the internal glands, which vary in the three forms. There is marked variation in the size of the compound eyes at the sides of the head. After Snodgrass Bull. Bureau Ent. 28. (Fig. 1.)

Let us attempt from three different points of view to attack these problems that seem so perplexing.

THE GENETICIST'S METHOD OF ATTACK

In the first place we may consider the matter as viewed by the geneticist. There are numerous instances of transmission of qualities that appear only under the influence of particular environmental conditions. The germ plasm of any species doubtless has potentialities that are realized only under exceptional circumstances or not at all. Thus the factor for extra legs in Drosophila is inherited as a sexlinked gene, but the character appears only if development takes place at a cold temperature. A study of genetic literature reveals many other examples of masking of Mendelian differences by environment. In stock of uniform genetic character there may be considerable variation as a result of change of food, temperature, humidity, etc.

It may then be answered that workers are of the same genetic constitution as the queen, but a difference of food has dwarfed the ovaries and caused a greater development of brain and in: strinets . The fact that superior instincts Haseriog occurred in any of the worker bee's dirèct ancestors is quite in line wits thị pioblem of heredity as viewed a roin the:aspect of cell lineage. We receive our hereditary characters not from the body cells of our parents, but from the germ tract extending back indefinitely. The somatic cells of our ancestors are "sisters" to their germ cells, and "aunts" and "great aunts" to our own, just as worker bees are sisters to queens and drones and aunts and great aunts to later generations of workers.

The germ plasm of the honey bee has the capacity to develop worker as well as queen qualities, and the difference between worker and queen is determined by the food of the larva.

The difficulty which appears in the derivation of drones from virgin queens, is again due to the idea that characters are inherited as such from the parent. The drone does not derive its characters from egg-laying workers or unmated queens. On the contrary it derives a simplex assortment of genetic factors or of chromosomes in the unfertilized egg. This simplex condition determines the male, just as the duplex determines the female. If honey-bees were able to lay unreduced eggs, as are various species of parasitic wasps and aphids, then females would be produced parthenogenetically. Or if two sperm 
nuclei could unite in an egg without an egg nucleus, then a female might result possessing all the racial characteristics of the father, but in every way a normal female.

The determination of sex then is not due to the source of the germinal material but rather to its quantity. In other words each caste,--drone, queen, or worker-transmits the very same genetic complex, including factors for racial differences in color, form, and instinct, and the genetic potentiality of producing male, queen or workeraccording to conditions. A simplex genetic assortment produces a male, a duplex produces a female, - a queen in case of royal feeding, a worker in case of worker feeding.

\section{THE PHYLOGENETIC POINT OF VIEW}

Let us consider the matter now from the point of view of phylogeny. What has caused the complicated instincts of the workers to be developed and what maintains these instincts at their present high level? In a word, how has natural selection acted upon the reproductive castes so carefully guarded and cared for by the workers?

For the one brief marriage flight of her life the queen must have strong wings to fly and keen senses to observe landmarks so that she may return to her hive. Failing in this one test she loses all chances of posterity. Moreover her mate must be superior to his fellows in speed of wing and sureness of vision. The marriage flight is indeed a eugenic test and selection of the superior male. Germ plasm then of queen and drone must bear factors for superior sensory apparatus and strong wings and muscles.

But the germ plasm of the royal pair must carry factors also for industry in collecting honey and pollen and in constructing combs and caring for the young or the colony as a whole will fail. Relatively high fertility must also be present for scarcity of eggs would result in small numbers of workers and scarcity of sperm would result in failure of fertilization giving excess of drones.

Natural selection acts upon the colony as a unit, and the character of the colony is genetically determined by the queen mother and her mate. The hive having greater industry, more socialized instincts, stronger wings and keener senses will survive under adverse conditions, show better capacity for adaptation, and thus have greater chances of posterity.

\section{THE PHYSIOLOGICAL POINT OF VIEW}

Finally from the physiological point of view there are numerous interesting problems concerning the differentiation of the castes.

It may be supposed that there are factors located in the various chromosomes tending to pull the course of development in the female direction. These would have a tendency to suppress male characters, both primary and secondary, but would stimulate the development of embryological fundaments of female characters. These factors are, however, too weak to act unless doubled, and hence the simplex condition produces a male, the duplex a female.

Queens and workers, although similar genetically; are distinct before they have had experience with the outer world. Differentiation is therefore due, not to active experience, but to feeding. A comparison mày be made here with a situation in poultry. If ovaries be removed from a pullet, male form and plumage are developed, as well as male instincts, voice, etc. Now the effect of worker food in bees has been degeneration, or rather failure of development, of the ovaries. The queen may then be compared to the normal egg-laying hen, while the worker may be compared to the hen with ovaries removed, possessing characters that are normally suppressed by ovarial activity.

\section{EGG-LAYING WORKERS}

Intergrades between sexual and worker castes normally occur in bumble-bees, and in the honey bee, intergrades, such as egg-laying workers, are not unusual. Worker larvae, developing near queen cells, obtain royal jelly 


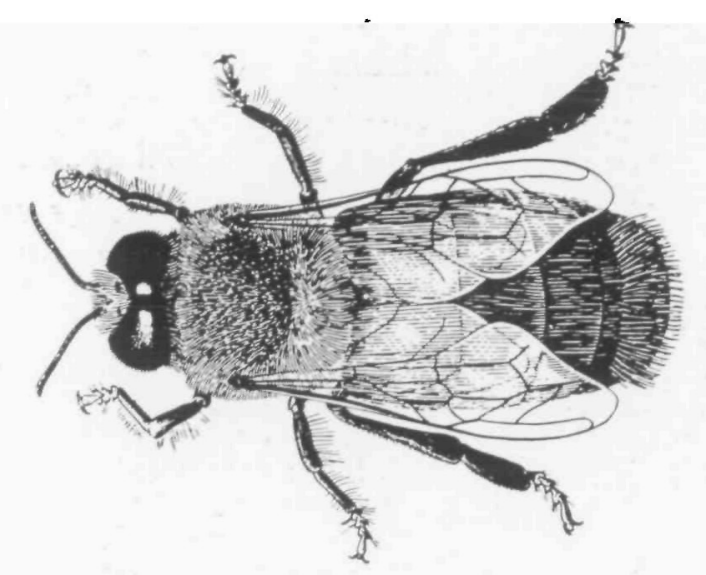

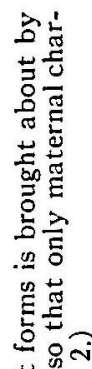

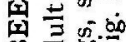

ต 苋

正.

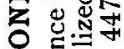

届

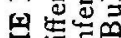

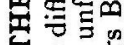

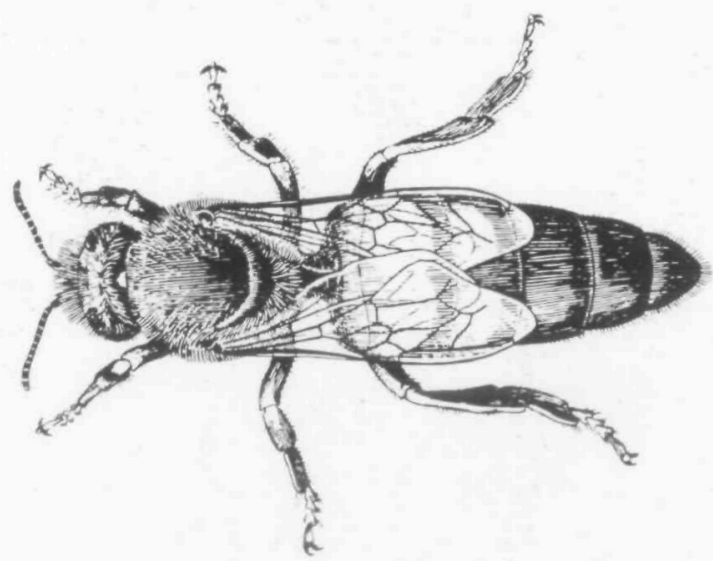

为至 혼

(4)

긍 के

两

A

A พ

安递

包出

的西

国 E5 它

은

可焉

된 응을

造造造焉

인

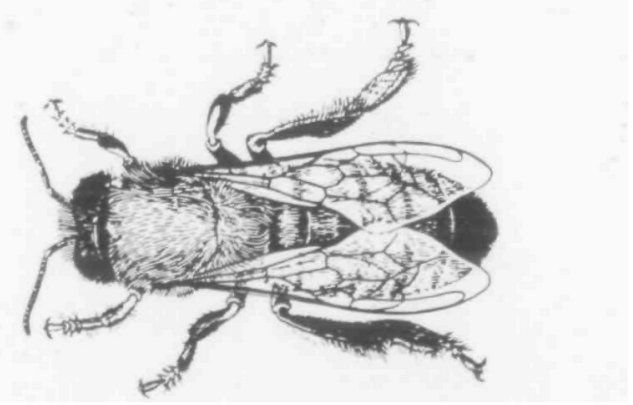

त

语要

吾苛

몰.놈

它焉

过

호늘

$=$ 공

Fo.

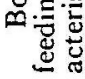



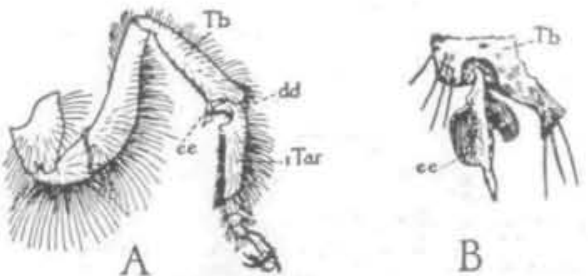

B
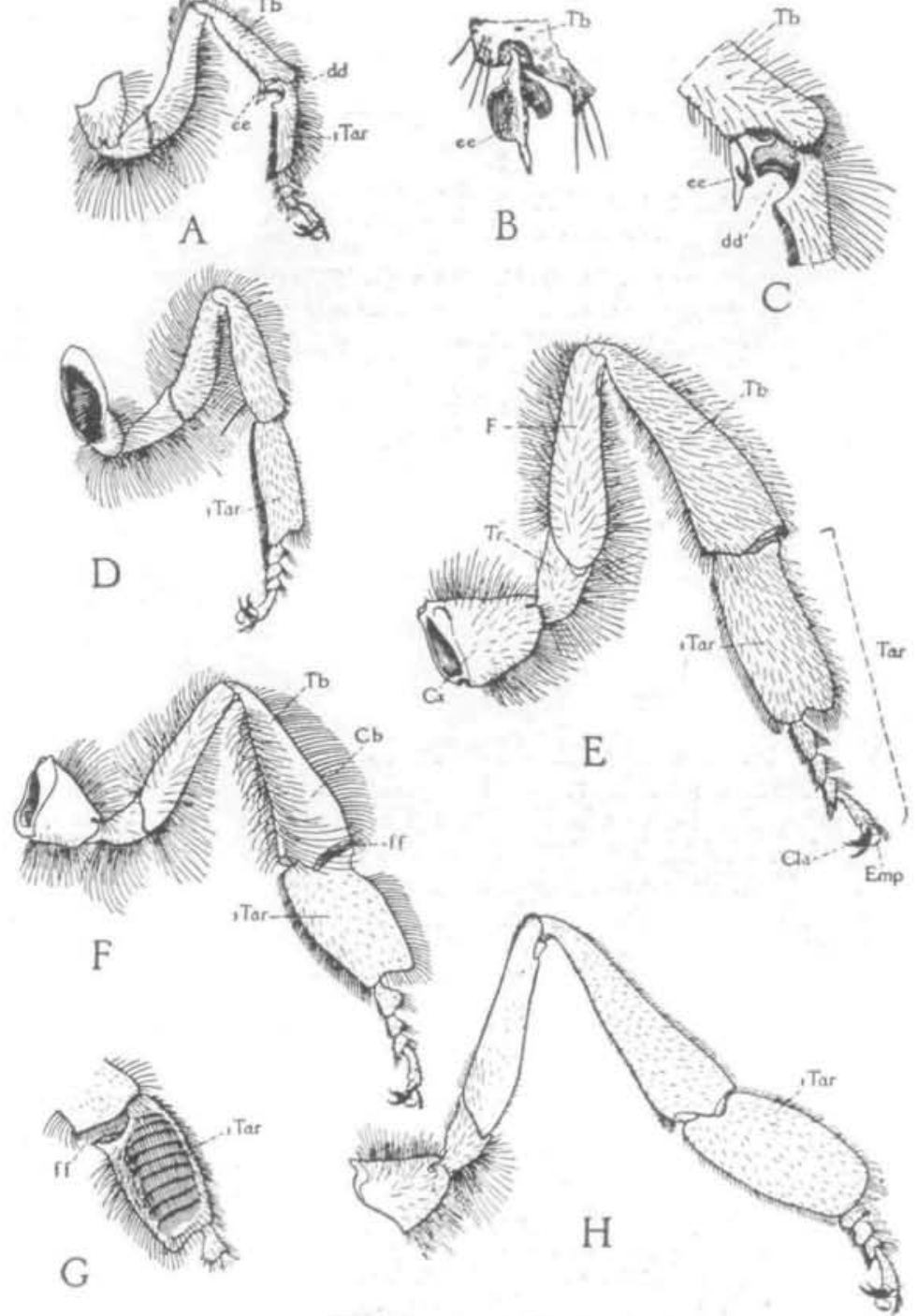

\section{LEGS OF HONEYBEES}

$A$, left front leg of worker, anterior view; $B$, Spine of antenna cleaner; $C$, Details of antenna cleaner; $D$, Left middle leg of worker, anterior view; $E$, Left hind leg of queen, anterior view; $F$, Left hind leg of worker, anterior view; $G$, Inner view of left hind leg of worker showing pollencombs; $H$, Left hind leg of drone, anterior view. The honeybee carries many of its tools as leg appendages and these vary in the three types of bees. After Snodgrass Bull. Bureau Ent. 18. (Fig. 3.) 
in addition to their regular worker food, and in this way are produced intermediate types resembling the bumble-bees in being capable of both work and reproduction, but probably of each to a lesser extent than the normal queen or worker. High specialization including differentiation of worker from queen has made for greater efficiency in the honey-bee colony.

\section{AN HEREDITARY NOTCH IN THE EARS OF JERSEY CATTLE}

\section{Superficial Appearance of This Character Would Appear to Fit Theory of Inheritance of Acquired Characters}

\section{JAY L. LUSH \\ Texas Agricultural Experiment Station}

$T$ $\mathrm{HE}$ principal Jersey sire of the dairy herd at the Texas A. \& M. College, Gamboge's Raleigh 109548 , is characterized by a peculiarly shaped ear which he has transmitted to a large number of his calves. The author's attention was called to this upon his arrival at the Texas Experiment Station last September, and through the co-operation of Prof. R. L. Pou, head of the Dairy Department and W. L. Pou, dairy herdsman, it has been possible to make a tentative analysis of the genetic situation.

The case is particularly interesting in that the oddness of the ear shape consists of a notch on the lower edge of the ear which is very similar to a mark commonly used on the range for identification, the so-called "undersloped" or "underbit" ear. Hence many a casual visitor would assume that the bull's ears were artificially "undersloped," and the fact that his calves are born with "undersloped" ears would apparently constitute proof that an acquired character is being inherited. The origin of the mark could not be learned, for this bull is now over nine years old and was bought as a suckling calf by C. S. Gainer, Bryan, Texas. Mr. Gainer noticed the mark distinctly at the time and there then seemed to be no sign of a scar. A letter addressed to The White Horse Farms, Paoli, Pennsylvania, breeders of this bull, did not receive a reply and it is not known whether his sire or dam had this mark. Therefore, it is necessary to start with this bull in studying the situation, since knowledge of the notch begins with him.

Only one other case similar to this has been found. The Jersey bull, "Fern's Texas Lad" 96298, which was owned at one time by J. F. Houchins, Hallettsville, Texas, "had both of his ears marked with an underslope and
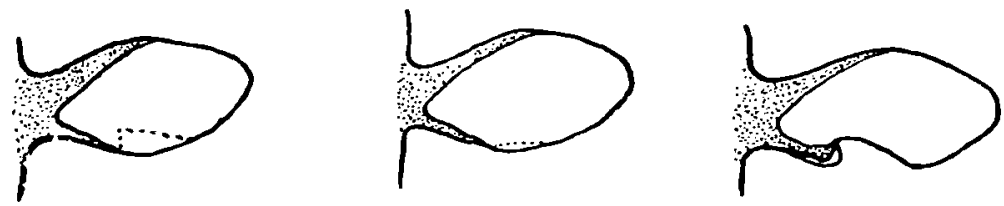

DIAGRAM SHOWING THE POSITION OF THE HEREDITARY NOTCH

On the left is shown the shape and position of the notch in the "underbit" ear, used as a mark by stockmen. The other two figures show the extreme variations in the size of the hereditary notch. (Fig. 4.)

1 Paper No. 1, in Animal Genetics, from the Texas Agricultural Experiment Station. 